\title{
The Effect of Stress Pattern on Iranian English Language Learners' Pronunciation
}

\author{
Lida Vafaei \\ Islamic Azad University of Takestan, Iran \\ E-mail: Vafaei.lida@yahoo.com \\ Marzieh Sadeghpour (Corresponding author) \\ Islamic Azad University of Takestan, Iran \\ Tel: 98-91-2466-2539Ｅ-mail: marziehsadeghpour@gmail.com \\ Mohammad Taghi Hassani \\ Ph.D, Islamic Azad University of Takestan, Iran
}

Received: June 18, 2013 Accepted: July 13, 2013 Published: July 14, 2013

doi:10.5296/ijele.v1i3.4011 URL: http://dx.doi.org/10.5296/ijele.v1i3.4011

\begin{abstract}
The present study investigated the stress pattern of Iranian English language learners' pronunciation. Participants were 30 intermediate EFL learners studying English in Jouya English institute in Tehran. In order to measure the level of the ability of the students in pronouncing the correct words in terms of their stress, 80 words selected from participants' text books. The words were divided into four groups according to the number of syllables and the place of stress; the first group consisted of 20 two-syllable words with stress on the first syllable, the second group was a 20 two-syllable words with stress is on the second syllable, the third group consisted of 20 three-syllable words with the stress was on the first syllable, and Lastly the fourth group included 20 three-syllable words with stress is on the second syllable. Participants were asked to read the words which were selected as a production test. Participants' performance was audiotaped to find out on which syllable of the word the stress is put. The results revealed that participants were more successful in pronouncing the words whose stress was on the first syllable in comparison to those having stress on the second syllable.
\end{abstract}

Keywords: phonology, pronunciation, suprasegmental features, stress, syllable. 


\section{Introduction}

What are the characteristics of a stressed syllable that enables us to identify them? It is important to understand that there are two different ways of approaching this question.

One is to consider what the speaker does in producing stressed syllable, and the other is to consider what characteristics of sound make a syllable seem to a listener to be stressed. Words' stress pattern can be studied from the point of view of production and perception, the two are obviously closely related, but are not identical (Roach, 1996). In fact, studying production and perception of stress is a substantive study of production and perception of the whole language. So, it is related to a chain of studies on the segmental and suprasegmental features of language like phonetics and phonology.

This study examined the basic issues of English stress patterns and gave an account to pronunciation and its role in learning and teaching English as a foreign language (EFL).

\section{Statement of the Problem}

One of the difficulties in pronunciation that many EFL Learners have is the accurate perception and production of word stress. Errors related to primary word stress are a common problem among EFL learners and have a great impact on students' pronunciation intelligibility and their perception skills (Celce-Murcia, Brinton, and Goodwin, 1996). Mostly this failure to understand the message leads to increased anxiety associated with activities that involve listening, such as English language tests, video conferences, conference talks, telephone calls, and academic or professional meetings.

Unfortunately, many EFL/ESL teachers do not pay enough attention to pronunciation practices in their classes, either because they have not been trained how to teach this skill (Derwing, Krahn, Foote, \& Diepenbroek, 2006), or because they think that pronunciation practice is too time consuming and they do not have time to address that in class (Celce-Murcia, Brinton, and Goodwin, 1996; Morley, 1994)

As far as EFL learners are concerned, they do not speak to native speakers most of the times, so they do not usually learn the supersgmental features (here word stress) of speech. But in the case of speaking to native speakers, they will encounter pronunciation problems in reality. Misinterpretation and lack of intelligibility is the result of such conversations.

By considering the importance of pronunciation, Iranian high school and university curricula, unfortunately, neglect the instruction of stress patterns in English teaching books, and it can be said that books are reading skill oriented. This study intended to highlight the importance of the speaking skill and its components, especially stress patterns of English language.

\section{Significance of the Study}

In an era of globalization, it is essential to have relationship with the people from other countries. With the current states of English as the world's prime lingua Franca, intelligibility will be the most important of speaking skill, and speaking itself becomes more and more important. Native speakers of English rely on word stress to recognize isolated words 
(Cooper, Cutler, \& Wales 2002; Slowiaczek, 1990), as well as words on the sentence level (Benrabah, 1997). Studying stress patterns in English is particularly important for speakers of other languages whose stress rules are more regular and/or different (Celce-Murcia et al, 1996) and this interferes with comprehensibility.

Effective word stress teaching therefore plays a non-negligible role in learners' instruction. Stressing words appropriately also improves vowel quality, or at least prevents it from being distorted, as it may result with incorrectly stressed words.

\section{Pronunciation Research in Applied Linguistics}

Although attaining native-like pronunciation that facilitates mutual intelligibility is considered important for many language learners and teachers alike, there have been few empirical studies of pronunciation in applied linguistics (Derwing \& Munro,2005; Levis, 2005). For example, Derwing and Munro (2005, p. 386) state that "it is widely accepted that suprasegmentals are very important to intelligibility, but as yet few studies support this belief." This claim is supported by other researchers such as Hahn (1994) and Levis (2005) who states that over the past 25 years there has been encouragement to teach suprasegmentals though very little pedagogy has been based on empirical research.

As Levis (2005) states, "instruction should focus on those features that are most helpful for understanding and should deemphasize those that are relatively unhelpful" (pp. 370-371). Munro (2008) echoes this point when stating that "it is important to establish a set of priorities for teaching. If one aspect of pronunciation instruction is more likely to promote intelligibility than some other aspect, it deserves more immediate attention." (p. 197). Of course, we must first know what the most important elements are to ensure optimal instruction and learning outcomes.

\section{The Reasons for Teaching Pronunciation}

One of the most urgent reasons for effective pronunciation instruction centers on the large number of non-native English speakers attending American colleges and universities. According to the Institute for International Education, these students numbered 547,867 in the 2000/2001 school year, with a substantial number serving as graduate teaching assistants. The increase in the hours of classroom instruction given by non-native speakers has led to a corresponding decrease in student satisfaction with the quality of instruction, due mainly to the reported difficulty following non-native classroom presentation (Ostrom, 1997, as cited in Aufderhaar, 2004).

According to Aufderhaar (2004), research in second language acquisition that suggested a departure from the traditional, bottom-up phonemic-based approach to teaching from a top-down orientation emphasizing suprasegmental or prosodic aspects such as rhythm, intonation, and duration revealed a need to increase the adult learners' awareness of suprasegmental patterns of the target language at the discourse level.

Moreover, Nation and Newton (2009) stated that the goal of pronunciation instruction is to increase the intelligibility of second language speakers although factors such as age, L1, 
perspectives, and attitudes of the learner can affect the learning of second language phonological system. "There is clear evidence that there is a relationship between the age at which a language is learned and the degree of foreign accent" (Patkowski, 1990, as cited in Nation \& Newton, 2009, p. 78). However, pronunciation has been identified as one of the important aspects of second language acquisition as it plays a crucial role in spoken conversational interactions and intelligibility.

\section{The Importance of Suprasegmental}

Pronunciation is always a difficult step in learning a second or foreign language, especially for adults. Learners may have acquired perfect reading and writing skills while still being unable to communicate functionally in L2.

Problems in pronunciation can be traced to segmental as well as suprasegmental difficulties. Although most previous research has been conducted on the segmental level, recent studies show that suprasegmentals may play a more important role than segmentals in the acquisition of a second language phonological system (Anderson, Johnson \& Koehler 1992, Derwing, Munro \& Wiebe, 1998). A cross-language study conducted by Dupoux, Pallier, Sebastian, and Mehler (1997) found that native speakers of French, a language with fixed word-final stress, have difficulties with the discrimination of nonwords that differ only in the position of stress (e.g., [va'suma] vs. [vasu'ma] vs. [vasuma']). By contrast, native speakers of Spanish do not have any difficulties as stress is contrastive in their language. On the basis of their finding, the authors argue that French listeners are "deaf" to stress contrasts because French, unlike Spanish, does not have lexical stress. Subsequently, Peperkamp and Dupoux (2002) proposed a typology of stress-deafness by testing stress perception in adult speakers of several languages: French, Finnish, Hungarian, and Polish. Speakers of some languages showed more robust "stress deafness" effects than did speakers of other languages. They found that French speakers exhibited the strongest effect of stress deafness among all languages as French is a non-stress language, whereas Spanish speakers had significantly lower scores than other languages on the stress deafness index, since Spanish is a stress language like English.

\section{Contrastive Analysis of English and Persian Stress Patters}

In order to see the most important differences between English and Persian, we can categorize them as follow:

a. Persian words pronounced in isolation have the strongest stress on one syllable. It is somewhat agreed that stress is predominantly on the final syllable of simple words.

$$
\begin{array}{ll}
\text { ketab' (book) } & \text { Ziba' (beautiful) } \\
\text { madar' (mother) } & \text { name' (letter) }
\end{array}
$$

There are nevertheless some exceptions to this claim; that is, inflectional endings, infinitives of verbs, when added to the dictionary entry form of the simple words, cause a shift of stress (see Ferguson, 1957). 


$\begin{array}{ll}\text { mir'-ravam. } & \text { (I go) } \\ \text { Ketab-ha' } & \text { (books) } \\ \text { Ziba-tar' } & \text { (more beautiful) } \\ \text { Name-rasan' } & \text { (mailman) }\end{array}$

In English, on the contrary, it is not so easily predictable. Knowing the number of syllables of the English words, one cannot predict the stress placement because the strongest stress could usually occur anywhere regardless of the grammatical functions of the words. It may fall on the first as in for'tunately, on the second as rheto'rical, on the third as in agricul'tural, on the fourth as in misrepresent'.

b. As far as the nominal compounds are concerned, the stress rule is different in both languages. In Persian it occurs finally but in English it falls on the first member of the compound.

c. In English, compounds consisting of a determiner plus a head let the stress move onto the second member of the combination. In Persian, it is on the first constituent.

d. The head noun in English compounds consisting of a modifier and a head receives the primary stress; in Persian, however, it is the modifier which carries the strongest accent.

e. Some nominal compounds and phrases in English could occur with two alternative stress patterns, as in White' House and white house'. In Persian, there is only one pattern corresponding to that, i.e. it is finally stressed.

f. The first and the last members of the adverbial phrases in English and Persian carry the primary stress respectively.

g. Interrogatives are stressed in Persian, but unstressed in English.

h. The negative prefixes are stressed in Persian but unstressed or less stressed in English.

\section{Research Questions}

Referring to the primary objectives of the study, the main research questions raised here are interrelated as follows:

1. Is there a significant difference in the performance of Iranian English language Learners in pronouncing two syllable words whose stress falls on the first syllable and the two syllable words whose stress falls on the second syllable?

2. Is there a significant difference in the performance of the Iranian English Language learners in pronouncing three syllable words whose stress falls on the first syllable and the three syllable words whose stress falls on the second syllable? 


\section{Methodology}

\subsection{Participants}

The Subjects were EFL learners studying English at intermediate level in Joya English institute in Tehran. Thirty students were studied in terms of the word stress performance. All of the students were female. The approximate age of the subjects was 18. All of them are studying English for the purpose of speaking English fluently in the future. In addition, mastering general vocabulary is vital for these students.

\subsection{Instruments}

The different instruments used in this research include the following:

\subsubsection{Words}

The words selected for the tests were selected from Interchange book 3, written by Richards (1998). The only criterion which was considered for choosing the word from the aforementioned book comes from this fact that all of the students were familiar to them. Therefore, 80 words were selected from the books. The words were divided into four groups according to the number of the syllables and the place of stress. The first group consisted of 20 two- syllable words, in which the stress falls on the first syllable. The second group was made of a 20 two- syllable words in which the stress in on the second syllable. As far as the third group is concerned, it consisted of 20 three-syllable words, in which the stress is on the first syllable. Lastly, the fourth group included 20 three-syllable words, in which the stress falls on the second syllable.

\subsubsection{The Production Test}

The students were asked to read the words selected as a production test. The students' performance was recorded by the researcher. Finally, the researcher listened the recorded voice to check the embedded words for their stress accuracy.

\subsection{Procedure}

The two classes involved in the study were randomly chosen from students studying English at in Joya English Institute in Tehran, Iran. Thirty students participated in the testing. All of them were female. The approximate age of the subjects was 18 . Then, the subjects were given a list of 80 words to read them. These words were classified into four groups including 20 two-syllable words having stress on the first syllable, 20 two-syllable words having stress on the second, 20 three-syllable words having stress on the first syllable, and 20 three-syllable words having stress on the second syllable. When they were pronouncing the selected words, they were asked to say the meaning of the words if they knew them because the researcher wanted to distract the students from the goal of the research. The students' voice was recorded by an Mp3 player. After all of the selected participants read or pronounced the words, along with their meanings, the researcher started to put 0 for the incorrect stress and 1 for the correct stress. Finally, the researcher analyzed the data by using SPSS 15. 


\section{Al Macrothink}

\section{Results and Discussion}

\subsection{Research Question 1}

Is there a significant difference in the performance of Iranian EFL learners in pronouncing two syllable words whose stress falls on the first syllable and the two syllable words whose stress falls on the second syllable?

In order to answer the first research question, data were analyzed and the results are shown in the following tables:

Table 1. Mean scores for two-syllable words having stress on the first and second syllable

\begin{tabular}{|l|l|l|l|l|}
\hline & Mean & $\mathrm{N}$ & $\begin{array}{l}\text { Std. } \\
\text { Deviation }\end{array}$ & Std. Error Mean \\
\hline $\begin{array}{l}\text { Two-syllable words having stress on } \\
\text { the first }\end{array}$ & 13.47 & 30 & 2.417 & .441 \\
\hline $\begin{array}{l}\text { Two-syllable words having stress on } \\
\text { the second }\end{array}$ & 10.97 & 30 & 3.275 & .598 \\
\hline
\end{tabular}

Table 2. Paired sample test two-syllable words having stress on the first and second syllable

\begin{tabular}{|c|c|c|c|c|c|c|}
\hline & Mean & Std. Deviation & Std. Error Mean & $\mathrm{T}$ & df & Sig (2-tailed) \\
\hline Pair 1 & 2.500 & 3.192 & .583 & 4.290 & 29 & 0.000 \\
\hline
\end{tabular}

As it has been indicated in Table 2, Paired sample ' $t$ ' test revealed a significant difference between two-syllable words in which the stress falls on the first syllable and those two-syllable words having stress on the second syllable in Iranian EFL context, where ' $t$ ' value was 4.290 and $P$ value was .000. In addition, by looking at Table 1, we realize that the participants were able to pronounce two-syllable words in which the stress falls on the first syllable better than those two-syllable words having stress on the second syllable because the mean scores of the first group (Two-syllable words having stress on the first) was 13.47, while it was 10.97 in the second group (Two-syllable words having stress on the second). By considering the results of table 1 and 2 , the first research hypothesis is rejected. Therefore, we 
can come to this conclusion that students were more successful in pronouncing the words whose stress is on the first syllable in comparison to those having stress on the second syllable.

\subsection{Second Research Question}

Is there a significant difference in the performance of Iranian English language learners in pronouncing three syllable words whose stress falls on the first syllable and the three syllable words whose stress falls on the second syllable?

Table 3. Mean scores for three-syllable words having stress on the first and second syllable

\begin{tabular}{|l|l|l|l|l|}
\hline & Mean & $\mathrm{N}$ & $\begin{array}{l}\text { Std. } \\
\text { Deviation }\end{array}$ & $\begin{array}{l}\text { Std. Error } \\
\text { Mean }\end{array}$ \\
\hline $\begin{array}{l}\text { Three-syllable words having stress on the } \\
\text { first }\end{array}$ & 14.27 & 30 & 2.377 & .434 \\
\hline $\begin{array}{l}\text { Three-syllable words having stress on the } \\
\text { second }\end{array}$ & 11.00 & 30 & 3.523 & .643 \\
\hline
\end{tabular}

Table 4. Paired sample test three-syllable words having stress on the first and second syllable

\begin{tabular}{|l|l|l|l|l|l|l|}
\hline & Mean & $\begin{array}{l}\text { Std. } \\
\text { Deviation }\end{array}$ & $\begin{array}{l}\text { Std. Error } \\
\text { Mean }\end{array}$ & $\mathrm{T}$ & $\mathrm{df}$ & $\begin{array}{l}\text { Sig } \\
\text { (2-tailed) }\end{array}$ \\
\hline Pair 1 & 3.267 & 3.216 & .587 & 5.564 & 29 & 0.000 \\
\hline
\end{tabular}

As it is clear from Table 3, three-syllable words in which the stress falls on the first syllable had a mean score of 14.27 and those three-syllable words having stress on the second had a mean score of 11.00. As indicated in table 4, paired sample ' $t$ ' test revealed a significant difference between three-syllable words in which the stress falls on the first syllable and those three-syllable words having stress on the second syllable in Iranian EFL context $(\mathrm{t}=5.564 ; \mathrm{P}=.000)$. By considering the results of these two tables, the second research hypothesis is rejected. Accordingly, we can come to this conclusion that students were more able to pronounce those three-syllable words whose stress is on the first syllable in comparison to those having stress on the second syllable. 


\section{Conclusion}

By considering the above results, if we accept that stress falls on the final syllable of a word in Persian, then students should be able to transfer the habit of putting stress on the second syllable when they are pronouncing English words but this is not the case as far as the results of this study is concerned. In summary, the pronunciation errors produced by the intermediate level students proved that Iranian English language learners could not transfer all the learned L1 habits into L2. Regarding the reasons behind these conclusions, the researcher believes that the teachers or instructors do not pay enough attention to the pronunciation of words by learners. When the researcher asked the participants, most of them believe that they have not been taught how to pronounce words correctly as far as primary or secondary stress is concerned. Some believe that even their teachers are not able to pronounce some words correctly. In conclusion, students were not able to put stress on the second syllable because they did not even know what stress means and how many kinds of stress they have in English. The researcher believes that teachers should devote a little time to teaching pronunciation and stress during instruction.

Furthermore, the researcher contends that the lack of appropriate pronunciation models results in students' developing their own pronunciation based on the input they receive from the media. According to the EFL teachers, intermediate level students have the ability to acquire native-like pronunciation; however, since Iranian teachers are non-native speakers of English themselves, they can only help students acquire intelligible pronunciation.

Another challenge for Iranian teachers teaching English pronunciation is the lack of materials. The books that are used in most language schools in Iran have a general approach towards language teaching which leaves teachers to design their own instruments for teaching pronunciation. Teachers meet this challenge by using listening, drilling, and repetition to teach pronunciation.

\section{Pedagogical Implications}

The findings of this study suggest a number of pedagogical implications for the pronunciation class in Iranian EFL context. First and foremost, by considering the results of this study, there seems to be a trend in students' progress with respect to English stress that could reflect a general trend in pronunciation development. In other words, students will be able to increase their knowledge of English stress significantly if they are taught well although their production will decrease a bit after instruction.

Second, one of the drawback of living in an EFL context like Iran is that students have little opportunity to practice their English pronunciation outside the class, while if this happens, it will increase their chance of improvement. Yet, it is the teacher's role to facilitate learning, and enhancing students' capabilities to improve on their own by empowering them with self-teaching strategies for their use in private.

Furthermore, to be able to promote in learners' effective self-monitoring and self-practicing strategies for improving pronunciation, teachers should be taught how to teach the strategies well because most of the teachers are not able to teach pronunciation effectively and efficiently. 


\section{Macrothink \\ International Journal of English Language Education \\ ISSN 2325-0887 \\ 2013, Vol. 1, No. 3}

\section{References}

Anderson-Hsieh, J., Johnson, R., \& Koehler, K. (1992). The relationship between native speaker judgments of nonnative pronunciation and deviance in segmentals, prosody, and syllable structure. Language Learning, 42(4), 529-555.

Aufderhaar, C. (2004). The influence of using discourse analysis techniques on the filtered speech of authentic audio text to improve pronunciation. Phd dissertation, University of Cincinnati.

Benrabah, M. (1997). Word-stress--A source of unintelligibility in English. IRAL: International Review of Applied Linguistics in Language Teaching, 35(3).

Celce-Murcia, M., Brinton, D., \& Goodwin, J. (1996). Teaching Pronunciation. Cambridge: Cambridge University Press.

Cooper, N., Cutler, A., \& Wales, R. (2002). Constraints of lexical stress on lexical access in English: Evidence from native and nonnative listeners. Language and Speech, 45, 207-28.

Derwing, T. M., \& Munro, M. J. (2005). Second Language Accent and Pronunciation Teaching: A Research-Based Approach. TESOL Quarterly, 39(3), 379-397.

Derwing, T., Krahn, H., Foote, J., \& Diepenbroek, L. (2006). The Attraction and Retention of Immigrants to Edmonton: A Case Study of a Medium Sized Canadian City. Working Paper \#05-05. Edmonton, AB: PCERII.

Falk, J. S. (1995). Roman Jakobson and the History of Saussurean Concepts in North American Linguistics. Historiographia Linguistica, 22(3), 335-367.

Ferguson, C. A. (1957). Word stress in Persian. Language, 33(2), 123-135.

Levis, J. M. (2005). Changing contexts and shifting paradigms in pronunciation teaching. TESOL Quarterly, 39(3), 369-377.

Nation, I. S. P., \& Newton, J. (2009). Teaching ESL/EFL listening and speaking. New York, NY: Routledge.

Peperkamp, S., \& Dupoux, E. (2002). A typological study of stress 'deafness'. In C. Gussenhoven \& N. Warner (Eds.), Laboratory Phonology 7, (pp. 203-240). Berlin: Mouton de Gruyter.

Roach, P. (1996). Emotions, attitudes and the English speaker, in: Speak Out! Changes in Pronunciation (Summer 1996), ed. Vaughan-Rees, M. CUP, Cambridge, U.K., pp. 45-49.

\section{Copyright Disclaimer}

Copyright reserved by the author(s).

This article is an open-access article distributed under the terms and conditions of the Creative Commons Attribution license (http://creativecommons.org/licenses/by/3.0/). 